\title{
PASIÓN DE LEER
}

\author{
Gabriela Mistral (1935)
}

\section{DAR UN APETITO}

La faena en favor del libro que corresponde cumplir a maestros y padres es la de despertar la apetencia del libro, pasar de allí al placer del mismo y rematar la empresa dejando un simple agrado promovido a pasión. Lo que no se hace pasión en la adolescencia se desmorona hacia la madurez relajada.

Volver la lectura cotidianidad, o según dice Alfonso Reyes, "cosa imposible de olvidar, como lavarse las manos". Dejar atrás el hábito de padres o abuelos que contaban los libros que habían leído por las catástrofes nacionales o los duelos de la familia. Hacer leer, como se come, todos los días, hasta que la lectura sea, como el mirar, ejercicio natural, pero gozoso siempre. El hábito no se adquiere si él no promete y cumple placer.

La primera lectura de los niños sea aquella que se aproxima lo más posible al relato oral, del que viene saliendo, es decir, a los cuentos de viejas y los sucedidos locales. Folklore, mucho folklore, todo el que se pueda, que será el que se quiera. Se trata del momento en que el niño pasa de las rodillas mujeriles al seco banco escolar, y cualquier alimento que se le allegue debe llevar color y olor de aquellas leches de anteayer. Estas leches folklóricas son esmirriadas en varias razas: en la española conservan una abundancia y un ímpetu de aluvión. No es cosa de que los maestros las busquen penosamente: hechas cuento o romance, corren de aldea a ciudad por el lomo peninsular; llegan a parecer el suelo y el aire españoles, y no hay más afán que cogerlas, como las codornices en la lluvia de Moisés, estirando la mano y metiendo en saco las mejores: casi no hay mejores y peores; posee el folklore español una admirable parejura de calidad en que regodearse.

Yerran los maestros que, celando mucho la calidad de la lectura, la matan al imponer lo óptimo a tirones y antes de tiempo. Debemos condescender algo o mucho con el niño, aceptándole ciertas lecturas o bobas o laterales. He visto a chiquititos bostezar por unas Ilíadas en versión llamada infantil y que se despabilaban en seguida por cualquier Julio Verne.

Aceptemos ladinamente el gusto zurdo del niño por la aventura mal escrita, que una vez hecho su "estómago de lector", la aventura sandia irá trepándose hacia Kipling y Jack London, y de éstos a otros, hasta llegar a la Divina Comedia (tremenda aventura por dentro del ánimo), al Quijote o al mundo de Calderón.

Dicen que lo mejor suele ser enemigo de lo bueno; también lo solemne anticipado puede empalagar de lo serio y por toda la vida. El fastidio lleva derecho a la repugnancia. 


\section{PASIÓN SUBIDA}

Pasión de leer, linda calentura que casi alcanza a la del amor, a la de la amistad, a la de los campeonatos. Que los ojos se vayan al papel impreso como el perro a su amo; que el libro, al igual de una cara, llame en la vitrina y haga volverse y plantarse delante en un hechizo real; que se haga el leer un ímpetu casi carnal; que se sienta el amor propio de haber leído los libros mayores de siempre y el bueno de ayer; que la noble industria del libro exista para nosotros por el gasto que hacemos de ella, como existen la de tejidos y alimentos, y que el escritor se vuelva criatura presente en la vida de todos, a lo menos tanto como el político o industrial.

Entonces y no antes, la lectura estará en su punto, como el almíbar; ni pedirá más, que fuese manía; ni aceptará menos, que sería flojedad.

Pasión de leer, seguro contra la soledad muerta de los hueros de la vida interna, o sea de los más. Sirviese la lectura solamente para colmar este hondón del fastidio, y ya habría cumplido su encargo.

Pasión preciosa de fojear el mundo por mano más hábil que la propia; pasión de recorrer lo no recorrido en sentimiento o acción; arribo a posadas donde dormir soñando unos sueños. Si no mejores, diferentes del propio. Y pasión del idioma, hablado por uno más donoso, o más ágil, o más rico que nosotros. Se quiere como a la entraña a la lengua, y eso no se sabe sino leyendo en escritura feliz un logro del prójimo, que nos da más placer que la nuestra, que nos llega a producir una alegría pasada a corporal, a fuerza de ser tan viva.

\section{MUDANZA DEL GUSTO}

El cine está habituando a los muchachos a un tipo de hazaña más rápida, más vertical. Bueno será que los novelistas morosos se den cuenta de este ritmo de la generación lectora que viene. El mismo cine les está retrotrayendo a la imaginación pura, tirada y reída por nuestros padres, que fueron educados en la calva Razón.

Ahora comienza, y también por el cine vilipendiado, el amor de la lectura manca de ciencias naturales. Es cuestión de aprovechar el suceso y sacarle el beneficio posible. Obreros he visto leyendo en una sala una Historia del Cielo, bien ilustrada, y sé que es corriente su gusto de la aventura animal, en vidas de abejas, de elefantes y de bichos estupendos...

\section{PACIENCIAS}

Por estos caminos de niñerías se puede llevar a cualquiera a la pasión de leer, hasta al lerdo y sordo, y sin más que alimentar esta avidez niña.

Lo único que importa es cuidar los comienzos: el no hastiar al recién llegado, el no producirle el bostezo o el no desalentarle por la pieza ardua. Ciencia de editor, o de 
bibliotecario, o de maestro: astucia de la buena, manejo de persona difícil, habilidad de entrenador.

Queden para después las limpias del material, los cuidados acérrimos del repertorio, la organización de los temas, según la ideología A o B.

Este postergar es un cuidar, un racional acomodamiento del huésped, antes de contarle la heráldica de la casa de los libros.

"La lectura distrae". No siempre nos distrae, es decir, nos aparta y nos pone a la deriva, porque muchas veces nos hinca mejor en lo nuestro. Da el regusto de lo vivido y es rumia de lo personal que hacemos sobre la pieza ajena; egoístas no dejamos de ser nunca, y en la novela resobamos percance o bienaventuranza propios.

\section{RELIGIOSO POÉTICO}

Los programas de lectura escolar u obrera no dejen de mano la poesía, o se quedarán muy plebeyos. La poesía grande de cualquier escuela o tiempo. Si lo es, tendrá garra como la bestia prócer o echará red en nosotros a lo barca de pesca.

Menos que la poesía debemos desdeñar de tontos desdenes la lectura religiosa. Escrituras sacras, todas, una por una, y nuestra Biblia la primera, valen por el más ancho poema épico, en resuello heroico y en forzadura cenital a sacrificio. Contienen además ellas una fragua tal de fuego absoluto, que sale de allí, cuando se las maneja a las buenas, un metal humano duro de romperse en el trajín de vivir y muchas veces apto para rehacer las vidas del mundo, cuando ellas crujen de averiadas. Los libros que hicieron tal faena, sin etiqueta de criatura religiosa, llevaban por el revés la vieja marca de la mística despedida y que regresa siempre.

Madrid, mayo de 1935, en Magisterio y Niño 